\title{
Wolf's Isotopic Response of Eosinophilic Dermatitis After Herpes Zoster Infection: Case Reports and Literature Review
}

\author{
Yuyan Yang (D), Tao Wang (D)
}

Department of Dermatology, State Key Laboratory of Complex Severe and Rare Diseases, Peking Union Medical College Hospital, Chinese Academy of Medical Science and Peking Union Medical College, National Clinical Research Center for Dermatologic and Immunologic Diseases, Beijing, People's Republic of China

Correspondence: Tao Wang, Department of Dermatology, State Key Laboratory of Complex Severe and Rare Diseases, Peking Union Medical College Hospital, Chinese Academy of Medical Science and Peking Union Medical College, National Clinical Research Center for Dermatologic and Immunologic Diseases, Beijing, People’s Republic of China, Tel/Fax +86 10-69I5I502, Email wangtaopumch@I26.com

\begin{abstract}
Wolf's post-zoster isotopic response refers to the occurrence of an unrelated new skin disorder at the same site of a healed skin lesion. Mechanism of this dermatological phenomena after herpes zoster infection remains unclear. In this study, we present three rare cases of eosinophilic dermatitis following herpes zoster infection. Erythematous infiltrative plaques or scattered red papules were found in all patients after remission of a previous herpetic infection. Skin biopsy revealed dermal perivascular eosinophilic infiltration, which was histologically confirmed as eosinophilic dermatitis. Based on the clinical timeline and histopathological characteristics, we supposed that the secondary lesion to be an isotopic response of Wolf. Skin lesion in one of the current patients overlapped with her tattoo, suggesting that tattoos might also predispose patients to post-zoster isotopic events. Topical corticosteroid was applied and all patients achieved remission. We also summarize the epidemiological, clinical and histopathological characteristics of the post-zoster eosinophilic dermatitis based on review of previous literature focusing on Wolf's isotopic response and secondary inflammatory dermatological disorders.
\end{abstract}

Keywords: Wolf's isotopic response, herpes zoster, eosinophilic dermatitis, tattoo

\section{Introduction}

Wolf's post-zoster isotopic response refers to the occurrence of a new cutaneous disorder at the same site as an unrelated, previously healed skin disease caused by herpes zoster infection. ${ }^{1}$ Various novel skin diseases could occur, including granulomatous dermatitis, malignancy and lymphoma. ${ }^{2,3}$ Eosinophilic dermatitis is a relatively rare secondary dermatosis, with only five cases of post-zoster eosinophilic dermatitis (PZED) reported previously. It is important to distinguish the suspected lesions from common relapses of herpes-zoster infection and primary inflammatory dermatitis. Herein, we describe another three cases of eosinophilic dermatitis arose from an isotopic response of Wolf and review the previously published literature focusing on PZED. ${ }^{4-7}$

\section{Case Reports}

The first patient was a 31-year-old female (patient 1) who developed scattered erythematous infiltrative plaques with persistent pruritus on her face, left chest and shoulder (Figure 1A). The skin lesion on her left chest overlapped with a tattoo. Three months before she was affected by herpes zoster virus, with groups of papules distributed over the same skin site. The previous skin disease achieved complete remission after regular valaciclovir treatment. Laboratory tests indicated positive antinuclear antibody $(1: 160$; normal, $<1: 40)$, with a relatively high CD4/CD8 ratio (2.53; normal 0.92.0). The histopathological examination of the biopsy taken from her lesion revealed perivascular mild eosinophilic infiltration, which confirmed the diagnosis of PZED. HZV-antigen was Immunologically negative. By applying Corticosteroid Ointment, her conditions quickly improved within two months (Figure 1B). 

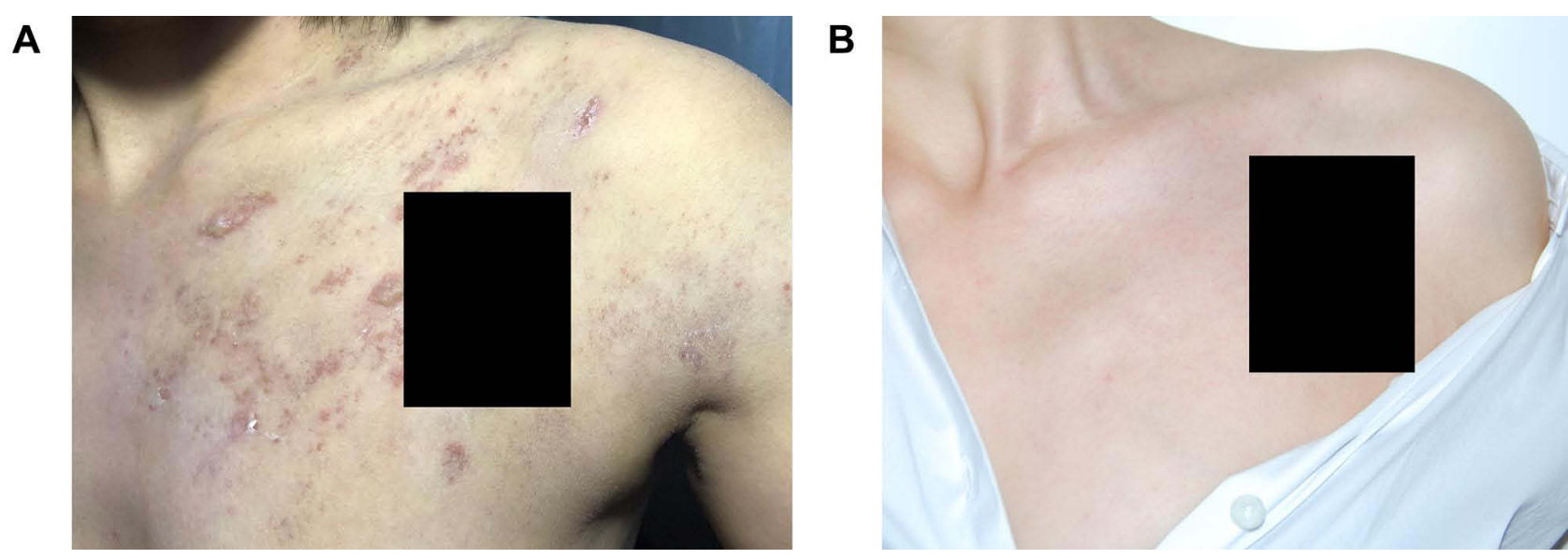

Figure I Skin lesions of patient I (tattoo was masked by black bars). (A) Erythematous papules and plaques on the left chest and shoulder. (B) Skin lesions healed after topical corticosteroid treatment.

A

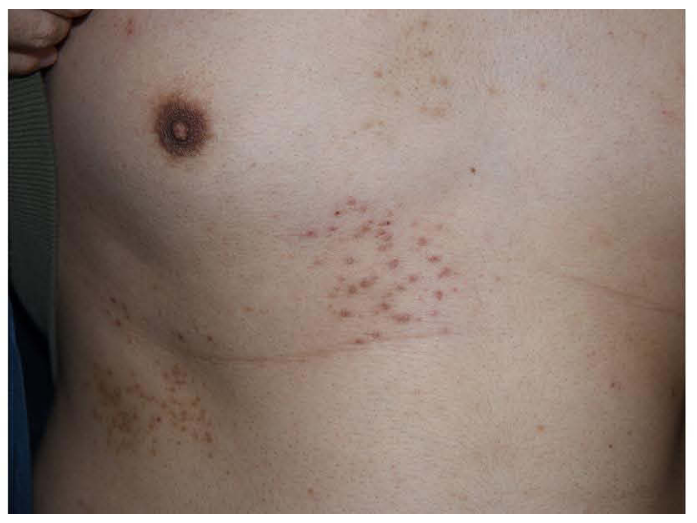

B

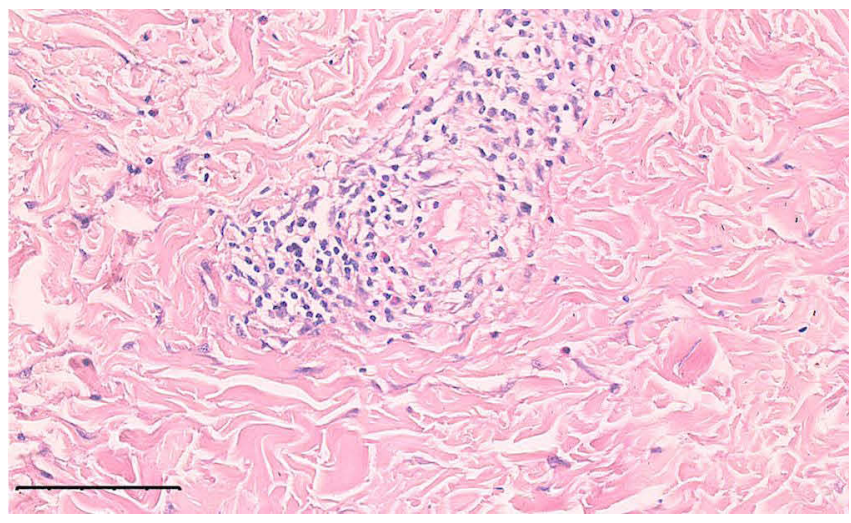

Figure 2 Skin lesions and histopathological results of patient 2. (A) Red papules along the T5-T7 dermatome on the right flank. (B) Dermis showing perivascular infiltration of eosinophils and lymphocytes. (Hematoxylin and Eosin staining - H\&E, magnification: I00x).

The second patient was a 31-year-old male (patient 2) presented with a 1-month history of pruritic and itching scattered red papules distributed on his right chest and flank (Figure 2A). He had been affected by herpes zoster five months previously, with skin lesions over the same area. The virus infection had been successfully treated by valaciclovir. Histopathological examination of the skin biopsy indicated dermal perivascular infiltration of inflammatory cells dominated by eosinophils and lymphocytes (Figure 2B). No HZV-antigen was detected in his blood sample or skin tissue. PZED was diagnosed and the lesions resolved over two weeks with topical Halometasone treatment.

The third patient was a 40-year-old male (patient 3) presented with extensive erythematous infiltrative plaques and scattered papules on the left chest noticed 1 month prior (Figure 3A). Five months before skin lesion caused by herpes zoster virus had been found distributed along the same dermatome, which was eliminated completely by valaciclovir. The secondary cutaneous lesion failed to respond to topical treatment by Ketoconazole, Diphenhydramine and Amorolfine. Finally, a histopathological examination was performed, demonstrating dense cellular infiltrates with eosinophils and other inflammatory cells (Figure 3B). No HZV-antigen was found in serum and skin tissues. Thus, diagnosis of PZED was confirmed. With the application of topical Mometasone Furoate, lesions gradually resolved within two months.

\section{Discussion}

Wolf's isotopic response (WIR) has been reported in more than 200 patients with various types of secondary dermatosis. Granulomatous reaction, including granuloma annulare and granulomatous dermatitis, was reported to be one of the most common subsequent diseases. ${ }^{3}$ However, eosinophilic dermatitis after herpes zoster infection has only been reported in 

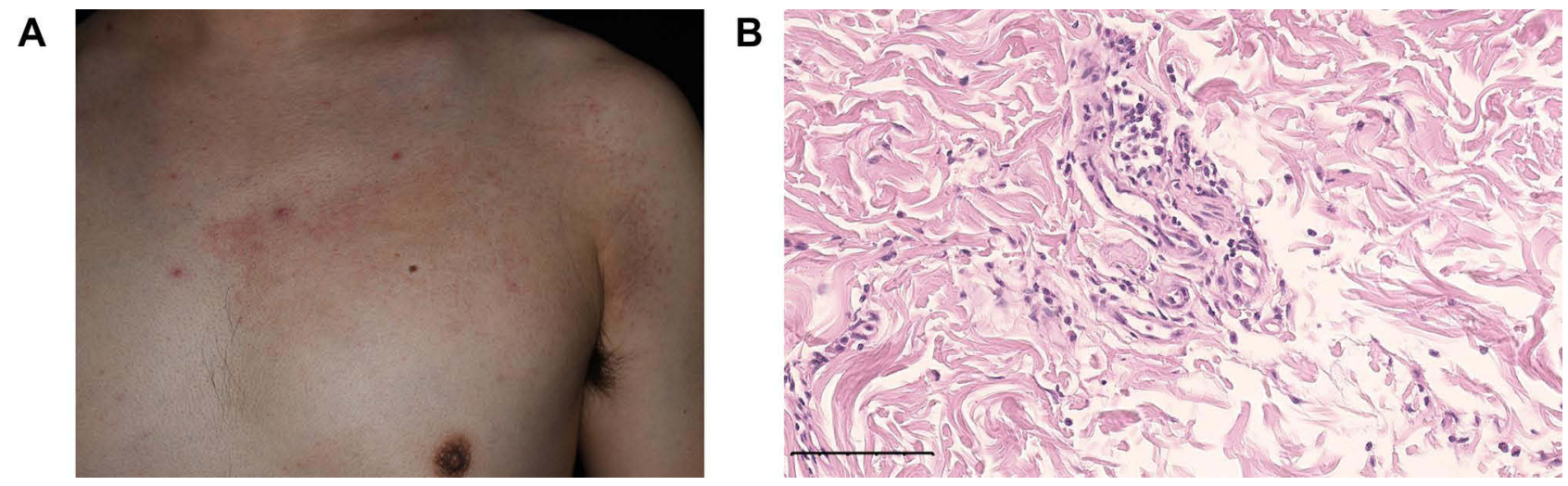

Figure 3 Skin lesions and histopathological results of patient 3. (A) Extensive erythematous infiltrative plaques and scattered papules on the left chest. (B) Dermis indicating dense infiltration with eosinophils and inflammatory cells (H\&E, I00x).

eight patients, including the three reported here (Table 1). ${ }^{4-7}$ No obvious pattern was found in terms of patient sex or age. Interestingly however, all published reports of PZED involved Asian individuals, probably related to ethnic characteristics and diagnostic methods. The time interval between the onset of eosinophilic dermatitis and herpes zoster infection varied from fifteen days to thirteen years. Lesioned areas of the secondary eosinophilic dermatitis seemed to be nonspecific, except for patient 1 in this report, in whom the lesions overlapped with a tattoo on her left chest. The common clinical features of PZED included erythematous infiltrative plaques and papules with pruritus, sometimes with itching. Histologically, dermal changes were characterized by perivascular eosinophils without granuloma, irrespective of the time interval between virus infection and eosinophilic dermatitis. However, two patients in whom the subsequent disease occurred after more than two years presented with more severe dermatological manifestations. ${ }^{4,5}$ We assumed that dermal impairment at the site of the preceding virus infection might persist in a subclinical state until triggered by internal of external factors, such as trauma or immunocompromised condition.

Wang et al have proposed a 4-group classification method of WIR based on dermatopathological changes. ${ }^{8}$ PZED hardly presents with epidermal or follicular changes, nor dermal tissue changes or malignant invasions. With characteristic perivascular eosinophils, PZED belongs to the inflammatory infiltration category in WIR.

Although the exact pathogenesis of PZED and WIR remains unclear, it can be partly explained by the neuro-immune impairment theory. Previous literature supposes a positive feedback cycle between neural injury, immune dysregulation and angiogenic changes, which initiates by the primary virus infection. ${ }^{8,9}$ Herpes zoster infection elicits the onset of PZED by damaging peripheral $\mathrm{A} \delta$ and $\mathrm{C}$ sensory nerve fibers, resulting in abnormal release of the neuropeptides. ${ }^{10}$ Apart from causing direct lesions, these neurotransmitters may also combine with membranous receptors on dermal immune cells to alter the local neuroimmune response. This immune destabilization may remain after virus clearance. After a period of accumulation, interleukin-4 induces eotaxin, leading to excessive eosinophils recruitment. ${ }^{6}$ This hypothesis is supported by the case of patient 1 in the current study, who had a relatively high CD4/CD8 ratio, representing a shift towards Th2-dominant cytokine production. The altered immune cell composition may further contribute to immune dysregulation. Apart from local immune dysfunction, Yoon and his team has also supposed that the immunocompromised state of the patient might also contribute to the activation of secondary dermatosis, such as granulomatous dermatitis.

Tattooing involves applying ink intraepidermally, and has been reported to activate herpes simplex infection, which histologically presented with multilocular eosinophilic inclusion bodies in the dermis. ${ }^{11,12}$ It is also thought to decrease local skin immunity, facilitating infection and inoculating virus remnants for later inflammation or reactivation. ${ }^{11,12}$ Supposedly, the overlaps between skin lesions and tattoo in patient 1 might thus not have been a coincidence. The patient was advised to continue regular follow-visits because of a potentially higher risk of PZED recurrence.

The Management for PZED has no consensus. Topical steroids, including topical Betamethasone, Halometasone and Mometasone, are usually applied for treatment. Lesions resolved without relapse in all reported patients. ${ }^{4-7}$ Patient 1 in our current study achieved remission even without erasing her tattoos, further indicating the effectiveness of steroid 
Table I Characteristics of Post-Zoster Eosinophilic Dermatitis in Previous Reports and the Present Cases

\begin{tabular}{|c|c|c|c|c|c|c|c|c|}
\hline Author & $\begin{array}{l}\text { Sexl } \\
\text { Age }\end{array}$ & Nationality & $\begin{array}{l}\text { Onset } \\
\text { After } \\
\text { HZI }\end{array}$ & Lesional Area & Clinical Manifestations & Pathology & Immunohistochemistry & Treatment \\
\hline $\begin{array}{l}\text { Mitsuhashi } \\
\text { et al. }{ }^{4}\end{array}$ & $\mathrm{~F} / 70$ & Japan & $\begin{array}{l}2.5 \\
\text { years }\end{array}$ & $\begin{array}{l}\text { Right lower } \\
\text { abdomen and } \\
\text { lumbar area }\end{array}$ & $\begin{array}{l}\text { Sharply demarcated brown } \\
\text { plaques }\end{array}$ & $\begin{array}{l}\text { Epidermal acanthosis and spongiosis, } \\
\text { dermal perivascular eosinophils, RBC } \\
\text { extravasation, no granuloma }\end{array}$ & NA & $\begin{array}{l}\text { Topical steroid } \\
\text { (not specific) }\end{array}$ \\
\hline Lee et al. ${ }^{5}$ & $\mathrm{~F} / 48$ & South Korea & $\begin{array}{l}13 \\
\text { years }\end{array}$ & Right flank & $\begin{array}{l}\text { Erythematous to brown plaques } \\
\text { and papules; scales }\end{array}$ & $\begin{array}{l}\text { Epidermal acanthosis and spongiosis, } \\
\text { dermal perivascular eosinophils, no } \\
\text { granuloma }\end{array}$ & NA & $\begin{array}{l}\text { Topical steroid } \\
\text { (not specific) }\end{array}$ \\
\hline $\begin{array}{l}\text { Miura } \\
\text { et al. }\end{array}$ & $\begin{array}{l}M / \\
69\end{array}$ & Japan & $\begin{array}{l}3 \\
\text { months }\end{array}$ & $\begin{array}{l}\text { Right chest and } \\
\text { back }\end{array}$ & Red plaques; pruritus & $\begin{array}{l}\text { Prominent eosinophils in dermis, no } \\
\text { granuloma }\end{array}$ & $\begin{array}{l}\mathrm{HZV} \text { antigen in sweat } \\
\text { glands; CD4+ and CD8+ } \\
\mathrm{T} \text { cells }\end{array}$ & $\begin{array}{l}\text { Topical steroid } \\
\text { (not specific) }\end{array}$ \\
\hline $\begin{array}{l}\text { Miura } \\
\text { et al. }{ }^{6}\end{array}$ & $\begin{array}{l}M / \\
72\end{array}$ & Japan & $\begin{array}{l}6 \\
\text { months }\end{array}$ & $\begin{array}{l}\text { Right chest and } \\
\text { back }\end{array}$ & $\begin{array}{l}\text { Erythematous infiltrative plaques } \\
\text { and papules; itching }\end{array}$ & $\begin{array}{l}\text { Dense eosinophils in dermis, RBC } \\
\text { extravasation, no granuloma, }\end{array}$ & $\begin{array}{l}\mathrm{HZV} \text { antigen in sweat } \\
\text { glands }\end{array}$ & $\begin{array}{l}\text { Topical steroid } \\
\text { (not specific) }\end{array}$ \\
\hline $\begin{array}{l}\text { Chen } \\
\text { et al. }\end{array}$ & $F / 49$ & China & 15 days & $\begin{array}{l}\text { Right trunk and } \\
\text { back }\end{array}$ & $\begin{array}{l}\text { Linear erythematous infiltrative } \\
\text { plaques and blisters; pruritus }\end{array}$ & $\begin{array}{l}\text { Dermal perivascular eosinophils and } \\
\text { lymphocytes, edema, vasodilation }\end{array}$ & NA & $\begin{array}{l}\text { Topical steroid } \\
\text { (Betamethasone) }\end{array}$ \\
\hline $\begin{array}{l}\text { Present } \\
\text { case I }\end{array}$ & $F / 3 I$ & China & $\begin{array}{l}3 \\
\text { months }\end{array}$ & $\begin{array}{l}\text { Left chest (overlap } \\
\text { with tattoo), } \\
\text { shoulder and face }\end{array}$ & $\begin{array}{l}\text { Erythematous infiltrative plaques; } \\
\text { pruritus }\end{array}$ & Dermal perivascular eosinophils & NA & $\begin{array}{l}\text { Topical steroid } \\
\text { (not specific) }\end{array}$ \\
\hline $\begin{array}{l}\text { Present } \\
\text { case } 2\end{array}$ & $\begin{array}{l}M / \\
31\end{array}$ & China & $\begin{array}{l}4 \\
\text { months }\end{array}$ & $\begin{array}{l}\text { Right chest and } \\
\text { flank }\end{array}$ & $\begin{array}{l}\text { Scattered red papules; pruritus } \\
\text { and itching }\end{array}$ & $\begin{array}{l}\text { Dermal perivascular eosinophils and } \\
\text { lymphocytes, edema, cellulose } \\
\text { degeneration }\end{array}$ & NA & $\begin{array}{l}\text { Topical steroid } \\
\text { (Halometasone) }\end{array}$ \\
\hline $\begin{array}{l}\text { Present } \\
\text { case } 3\end{array}$ & $\begin{array}{l}M / \\
40\end{array}$ & China & $\begin{array}{l}5 \\
\text { months }\end{array}$ & Left chest & $\begin{array}{l}\text { Extensive erythematous } \\
\text { infiltrative plaques; scattered red } \\
\text { papules; pruritus and itching }\end{array}$ & $\begin{array}{l}\text { Dermal perivascular eosinophils and } \\
\text { lymphocytes }\end{array}$ & NA & $\begin{array}{l}\text { Topical steroid } \\
\text { (Mometasone) }\end{array}$ \\
\hline
\end{tabular}

Abbreviations: $\mathrm{HZI}$, herpes zoster infection; HZV, herpes zoster virus. 
liniment. Application of antiviral therapy remains controversial. Considering previously reported failure and the inconsistency of herpes zoster virus at lesion found in our study, antiviral agents are not recommended for general use. ${ }^{13}$

\section{Conclusion}

In conclusion, we report three cases of PZED and review a further five cases from the literature. PZED usually presents as erythematous plaques and papules, and a longer interval between infection and eosinophilic dermatitis might result in more severe secondary skin lesions. Although the pathogenesis of PZED remains uncertain and need further researches, topical steroids are experiencedly recommended to achieve total remission.

\section{Informed-Consent Statement}

Written informed consent was obtained from all patients for their case details and accompanying images to be published in this paper.

\section{Acknowledgments}

The authors thank the patients for participating in this study. We also thank Susan Furness, PhD, from Liwen Bianji, Edanz Editing China (www.liwenbianji.cn/ac), for editing the English text of a draft of this manuscript.

\section{Funding}

This work was supported by Beijing Natural Science Foundation (Z210017).

\section{Disclosure}

The authors report no conflicts of interest related to the work in this manuscript.

\section{References}

1. Wolf R, Brenner S, Ruocco V, Filioli FG. Isotopic response. Int J Dermatol. 1995;34:341-348. doi:10.1111/j.1365-4362.1995.tb03616.x

2. Wolf R, Wolf D, Ruocco E, Brunetti G, Ruocco V. Wolf's isotopic response. Clin Dermatol. 2011;29:237-240. doi:10.1016/j. clindermatol.2010.09.015

3. Yoon JH, Jang YJ, Park EJ, Kim KJ, Kim KH. A case of herpes zoster granulomatous dermatitis: report of wolf's isotopic response. Ann Dermatol. 2021;2:186-189. doi:10.5021/ad.2021.33.2.186

4. Mitsuhashi Y, Kondo S. Post-zoster eosinophilic dermatosis. Br J Dermatol. 1997;136:465-466. doi:10.1111/j.1365-2133.1997.tb14966.x

5. Lee JH, Kim HS, Kim HO, Park YM. A case of post-zoster eosinophilic dermatosis. Ann Dermatol. 2009;21:274-276. doi:10.5021/ ad.2009.21.3.274

6. Miura T, Matsumura N, Hiraiwa T, Yamamoto T. Post-herpetic eosinophilic papules and plaques. Int J Dermatol. 2015;54:e82-84. doi:10.1111/ ijd. 12647

7. Chen K, Zhang M, Wang Y, Yang XX. Wolf's isotopic response: a case of postherpetic eosinophilic dermatosis. J Clin Dermatol. 2018;47:571-573. doi:10.16761/j.cnki.1000-4963.2018.09.008

8. Wang T, Zhang M, Zhang Y, et al. Wolf's isotopic response after herpes zoster infection: a study of 24 new cases and literature review. Acta Derm Venereol. 2019;99:953-959. doi:10.2340/00015555-3269

9. Mahajan R, De D, Saikia UN. Wolf's isotopic response: report of a case and review of literature. Indian J Dermatol. 2014;59:275-282. doi:10.4103/0019-5154.131401

10. Ruocco V, Sangiuliano S, Brunetti G, Ruocco E. Beyond zoster: sensory and immune changes in zoster-affected dermatomes: a review. Acta Derm Venereol. 2012;92:378-382. doi:10.2340/00015555-1284

11. Khunger N, Molpariya A, Khunger A. Complications of tattoos and tattoo removal: stop and think before you ink. J Cutan Aesthet Surg. 2015;8:30-36. doi:10.4103/0974-2077.155072

12. Begolli Gerqari A, Ferizi M, Kotori M, et al. Activation of herpes simplex infection after tattoo. Acta Dermatovenerol Croat. 2018;26:75-76.

13. Langenberg A, Yen B, LeBoit PE. Granulomatous vasculitis occurring after cutaneous herpes zoster despite absence of viral genome. $J$ Am Acad Dermatol. 1991;24:429-433. doi:10.1016/0190-9622(91)70066-b 


\section{Publish your work in this journal}

Clinical, Cosmetic and Investigational Dermatology is an international, peer-reviewed, open access, online journal that focuses on the latest clinical and experimental research in all aspects of skin disease and cosmetic interventions. This journal is indexed on CAS. The manuscript management system is completely online and includes a very quick and fair peer-review system, which is all easy to use. Visit http://www. dovepress.com/testimonials.php to read real quotes from published authors.

Submit your manuscript here: https://www.dovepress.com/clinical-cosmetic-and-investigational-dermatology-journal 